\title{
Why Husserl's Universal Empiricism is a Moderate Rationalism
}

\author{
Philipp Berghofer ${ }^{1}$ (D)
}

Received: 23 February 2018 / Accepted: 28 June 2018 / Published online: 4 July 2018

(c) The Author(s) 2018

\begin{abstract}
Husserl claims that his phenomenological-epistemological system amounts to a "universal" form of empiricism. The present paper shows that this universal moment of Husserl's empiricism is why his empiricism qualifies as a rationalism. What is empiricist about Husserl's phenomenological-epistemological system is that he takes experiences to be an autonomous source of immediate justification. On top of that, Husserl takes experiences to be the ultimate source of justification. For Husserl, every justified belief ultimately depends epistemically on the subject's experiences. These are paradigms of empiricist claims and thus Husserl seems to subscribe to empiricism. However, what is universal about Husserl's "empiricism" is that he does not limit the concept of (justification-conferring) experiences to sensory experiences or sensory experiences plus introspective intuitions but broadens the concept of experience such that also a priori intuitions are included. Husserl insists that logical, mathematical, and phenomenological intuitions such as $\sim(p \wedge \sim p)$, $2+2=4$, and "Experiences necessarily bear the mark of intentionality" provide noninferential justification analogous to how sensory experiences can non-inferentially justify beliefs such as "There is a table in front of me." Importantly, Husserl makes clear that such a priori intuitions are not about our concepts but about reality. This is why Husserl's universal empiricism is a rationalism. Husserl differs from traditional rationalism as he allows that a priori intuitions can be fallible and empirically underminable. This distinguishes Husserl's rationalism from Descartes' and makes him a proponent of moderate rationalism as currently championed by Laurence BonJour.
\end{abstract}

Keywords Husserl · Phenomenology $\cdot$ Epistemology $\cdot$ Rationalism $\cdot$ Intuitionism $\cdot$ A priori justification

Philipp Berghofer

philipp.berghofer@uni-graz.at

1 Department for Philosophy, University of Graz, Heinrichstraße 26/6, 8010 Graz, Austria 


\section{Husserl's Universal Empiricism}

Husserl is neither a traditional empiricist nor is he a traditional rationalist. He incorporates as well as condemns certain elements from both traditions. One might expect that for Husserl scholars it is a difficult matter to determine in what sense Husserl is an empiricist and in what sense he is a rationalist. Luckily, however, Husserl does a pretty good job in clarifying this for us. Here we find the most enlightening passage in his Encyclopaedia Britannica article:

Empiricism can only be overcome by the most universal and consistent empiricism, which puts in place of the restricted [term] 'experience' of the empiricists the necessarily broadened concept of experience, namely originary presentive intuition, which in all its forms (intuition of eidos, apodictic evidence, phenomenological intuition of essence, etc.) shows the manner and form of its legitimation through phenomenological clarification. Phenomenology as eidetics is, on the other hand, rationalistic: it overcomes restrictive and dogmatic rationalism, however, through the most universal rationalism of inquiry into essences, which is related uniformly to transcendental subjectivity, to the I, consciousness, and conscious objectivity. (Husserl 1971, 89; translation modified)

This passage reveals Husserl's commitment to the following theses:

\section{P1: Empiricism must be overcome}

P2: The concept of experience must be broadened such that every originary presentive intuition counts as experience

P3: Eidetic intuition is a subclass of originary presentive intuition. ${ }^{1}$

P4: This inclusion of eidetic intuition is a commitment to rationalism. ${ }^{2}$

P5: Husserl's rationalism must be distinguished from restrictive dogmatic rationalism

P6: Husserl's rationalism is interested in eidetic intuitions about the structures of consciousness

\footnotetext{
1 This means that eidetic intuitions, just as perceptual experiences, have the character of originary givenness. For more details on what it precisely means for an experience to be originally presentive and on the epistemological significance of the conception of originary givenness cf. Berghofer (2018b, c).

${ }^{2}$ In the course of this paper, we will see in detail why Husserl (rightly) believes that the inclusion of eidetic intuition amounts to a commitment to rationalism. The basic idea is as follows. Just as perceptual experiences are a source of immediate justification concerning physical reality, eidetic intuitions are a source of immediate justification concerning essences. This includes logical, mathematical, and phenomenological truths. Importantly, these truths are not mere fictions or conventions but as objective as it gets within a Husserlian framework.
} 
In the course of this paper, we shall see that Husserl's epistemological ${ }^{3}$ system qual- $^{-}$ ifies as a rationalism and not as an empiricism. This is because Husserl holds that a priori justification is possible and that a priori intuitions, ${ }^{4}$ at least sometimes, are not about our concepts but tell us something about reality. Husserl's version of rationalism qualifies as a moderate rationalism since, in contrast to Descartes, he allows that a priori justification can be fallible and empirically underminable. But let us proceed step by step. Let us begin with P1. Why does Husserl think that empiricism must be overcome?

Husserl's attack on empiricism begins in the Prolegomena but never loses its validity. His refusal of empiricism is not always as obvious as in the Prolegomena but it is omnipresent in his oeuvre and his whole epistemological project is shaped by this refusal. What he denies is empiricism's negative thesis that a priori justification either does not exist or only tells us something about our concepts, but not about reality. In the Prolegomena Husserl's main target is psychologism. According to psychologism, logical truths can be reduced to psychological truths. More precisely, Husserl defines psychologism as the following thesis:

The essential theoretical foundations of logic lie in psychology, in whose field those propositions belong - as far as their theoretical content is concerned which give logic its characteristic pattern. Logic is related to psychology just as any branch of chemical technology is related to chemistry, as land-surveying is to geometry etc. (Husserl 2001a, 40)

In this context Husserl quotes Mill, who refers to logic as a "branch of psychology" that "owes all its theoretical foundations to psychology." (2001a, 40) The main objective of Husserl's Prolegomena is to refute this thesis. For the present paper, it is important to note that psychologism is only one version of empiricism. A refutation of psychologism thus does not amount to a refutation of empiricism as such.

\footnotetext{
${ }^{3}$ It is to be noted that Husserl scholars are divided on the question of whether transcendental phenomenology can be regarded as an epistemological project or as having epistemological implications, at least given how epistemology is currently understood in the analytic tradition. For this reason, an anonymous referee of this journal has suggested avoiding the term "epistemological" in the context of Husserl's phenomenology. Hence, I would like to point out that I deliberately refer to certain Husserlian theses as constituting an epistemological system and having epistemological implications. I hope that this paper reveals systematically significant links and similarities between Husserl's theses and reasoning and certain movements within the analytic traditions. Elsewhere, I have argued in detail that Husserl's system is epistemologically relevant and illustrated how it could enrich current debates in epistemology (cf. cleared for anonymous review).

${ }^{4}$ In this paper I will use eidetic intuition and a priori intuition synonymously. Eidetic intuitions are a priori in a twofold sense: They are (a) different and epistemically independent from sensory (and introspective) experiences and (b) they do not have (properties of) spatio-temporal beings but essences as their objects. Thus, it is uncontroversial that every eidetic intuition is an a priori intuition. Many passages in Husserl's oeuvre suggest that Husserl identifies eidetic intuitions with a priori intuitions, which would mean that also every a priori intuition is an eidetic intuition. Such passages can be found when Husserl identifies a priori sciences with eidetic sciences (cf. the introduction to Ideas I) or when he states that "every a priori" leads to the "ideal realm of pure possibilities and eidetic necessities." (2002b, 295 f.) I would like to point out that since I am only concerned with eidetic intuitions, nothing in this paper hinges on whether there could be other forms of a priori intuitions.
} 
Importantly, Husserl is aware of this and while in the Prolegomena he is mostly concerned with refuting psychologism, there is a subsection in which he formulates objections against empiricism as such. This subsection is entitled "On certain basic defects of empiricism" and is an appendix to the paragraphs 25 and 26 appearing at the end of paragraph 26 (Husserl 2001a, 59-61). It seems to me that while Husserl's criticism of psychologism is well-received and much discussed, this general criticism of empiricism does not get the attention it deserves.

The aim of this subsection is to "expose the basic errors of empiricism." First, he targets what he calls "extreme empiricism." This is the kind of empiricism that can be ascribed to Mill, according to which logical truths and epistemological principles in general are not justified a priori but can only be justified on empirical grounds. ${ }^{5}$ Husserl insists that such an "[e]xtreme empiricism is as absurd a theory of knowledge as extreme skepticism. It destroys the possibility of the rational justification of mediate knowledge, and so destroys its own possibility as a scientifically proven theory." (Husserl 2001a, 59) To put it differently, if extreme empiricism is true, mediate (=inferential) justification and knowledge would be impossible. In Sect. 2, we shall see that currently Laurence BonJour has put forward the precise same argument against empiricism and concludes that empiricism leads to "intellectual suicide."

However, let us discuss Husserl's argument in more detail.

(1) Inferential justification/knowledge is possible.

(2) If a belief is inferentially justified, there need to be underlying principles of grounding (Begründungsprinzipien) that provide epistemic legitimacy to the inference in question.

(3) A vicious regress or vicious circle of such principles of grounding can only be avoided if there are ultimate principles ${ }^{6}$ that can be immediately grasped. ${ }^{7}$

(4) Extreme empiricism cannot allow for the immediate grasping of principles.

Conclusion: Extreme empiricism leads to an untenable version of skepticism according to which inferential justification/knowledge is impossible.

Husserl puts it as follows:

\footnotetext{
5 "On empirical grounds" basically means through experiences and induction. Note that the term "experiences" here is used in the empiricist way that includes only sensory and introspective intuitions but not a priori intuitions.

${ }^{6}$ Unfortunately, Husserl is not clear on what he takes to be the ultimate principles. I suggest considering Husserl's principle of all principles that implies that every originary presentive intuition is a source of immediate justification (Husserl 1982, 44) combined with the claim that originary presentive intuitions are the ultimate source of justification (Husserl 1982, 36) as the ultimate phenomenological-epistemological principles. We will discuss these passages in more detail below. In this context cf. also Berghofer (2018b).

${ }^{7}$ Immediately grasping a principle $\mathrm{P}$ means having an eidetic intuition that is originally presentive with respect to P. Thus, intuitions must not be confused with principles. Eidetic intuitions can be directed at principles, they can justify principles. I would like to thank an anonymous referee of this journal for pressing me to clarify the relationship between principles and eidetic intuitions.
} 
Thus, it is evident that the demand for a fundamental justification of all mediate knowledge can only have a sense if we can both insightfully and immediately grasp certain ultimate principles on which all proof in the last instance rests. All principles which justify possible inferences must therefore be deductively inferrible from certain ultimate, immediately evident principles, so that even the principles of the deduction in question all themselves occur among such principles. Extreme empiricism, therefore, since it only basically puts full trust in singular judgments of experience - a quite uncritical trust since it ignores the difficulties which so richly attend upon such singular judgments eo ipso abandons all hope of rationally justifying mediate knowledge. It will not acknowledge as immediate insights, and as given truths, the ultimate principles on which the justification of mediate knowledge depends; it thinks it can do better by deriving them from experience and induction, i.e. by justifying them mediately. (Husserl 2001a, 60; translation modified)

Note that extreme empiricism would not deny premises (1), (2), or (4). All hinges on premise (3). Here the main problem for empiricism is that it cannot provide a satisfying answer to the question why certain types of inference are permissible. Empiricists usually admit that deduction and induction are permissible types of inferential reasoning. Why? Empiricists cannot say that they immediately grasp that deduction and induction are permissible. Neither can they say that they immediately grasp a more fundamental principle from which it follows that deduction and induction are permissible. Furthermore, sensory experiences cannot justify induction and it seems viciously circular to claim that induction justifies induction. In the spirit of Quine, empiricists might respond that our holistic web of beliefs provides justification for deduction and induction, but if it is true that coherence is epistemically significant, the question arises of why this is so. Rationalists can admit that it can be immediately grasped that coherence is an important epistemic factor. ${ }^{8}$ Empiricists cannot. In short, I believe that Husserl's argument against empiricism is sound. In Sect. 2, we shall see that such a line of reasoning still plays an important role in contemporary debates in analytic epistemology.

Husserl points out that the argument cannot only be used against extreme empiricism but also against the more moderate empiricism he ascribes to Hume. Hume's empiricism is more moderate in the sense that it admits that logic and mathematics are a priori sciences whose axioms can be immediately grasped. It restricts empiricism to the factual sciences in the sense that it claims that mediate judgments of facts (mittelbare Tatsachenurteile) cannot be rationally justified but only psychologically explained (Husserl 2001a, 74). Husserl objects that this presupposes the legitimacy of psychology but since psychological insights are themselves mediate judgments of facts, psychology, according to the Humean empiricism, cannot be justified and thus lacks legitimacy (Husserl 2001a, 61). Thus, empiricism fails since it

\footnotetext{
${ }^{8}$ Of course, foundationalists must deny that coherence is the only relevant epistemic factor (for more details cf. Berghofer (2018a).
} 
inevitably leads to skepticism. ${ }^{9}$ This is (one of the reasons) why Husserl holds that empiricism must be overcome.

Importantly, Husserl's early Prolegomena is not the only place where Husserl forcefully argues against empiricism. The same is true for his claims that epistemological principles must be a priori graspable and that even empirical sciences and insights depend in some sense on such underlying a priori graspable principles. In his Introduction to Logic and Theory of Knowledge (lectures 1906/7) Husserl explicitly states that "[a]ll principles in the strict, genuine sense belong" to the sphere of the a priori and that this includes all epistemological principles (Erkenntnisprinzipien) (Husserl 1984, 232). He continues, saying,

All reason in the a posteriori has its principles a priori, and these principles are the grounds of justification of the objective, unconditional validity that every operation of so-called reason claims in both the theoretical and axiological spheres. Bringing principles to light everywhere and testing their authenticity, solving transcendental problems regarding them, therefore tracing them back to their phenomenological origin and meaning, showing them in the realm of intuitive essences to be the authentic matrix of knowledge as givens of seeing reason, or rejecting them as absurdities, that is the true philosophical task. (Husserl 2008, 233)

This passage tells us that for Husserl philosophy is first and foremost epistemology whose primary task is to discover and elucidate the ultimate a priori principles that are the ultimate grounds of all rationality and legitimacy. So far, we have not delivered a precise definition of what a priori insight exactly means. Shortly before the quoted passage, Husserl provides the following definition: A priori intuited is "what generally is certain to me while I question all experience and all transcendent assumptions, and is certain to me, not because it incidentally strikes me as that, but rather because in pure beholding I see the state of affairs as irrevocably grounded in the immanent essence of the concepts concerned." ${ }^{10}$ (Husserl 2008, 231) Note that here "experience" is used in the empiricist sense that only includes sensory and introspective experiences. Husserl gives a negative and positive characterization of the a priori. A priori insights are justificatorily independent of experiences. My a priori insight that $2>1$ is not in need of justificatory support by empirical insights. Even if I question all empirical insights, my insight that $2>1$ does not lose its justification. It is to be noted that this does not mean that even if I never had any

\footnotetext{
9 In Husserl (1984, 348-355) Husserl reinforces this objection against Hume's empiricism but notes that Hume does not overlook the skeptical consequences of his position but embraces them. For Husserl, such consequences are unacceptable and he points out that they can be easily avoided by subscribing to the possibility of immediate grasping of general principles such as the "principles of probability" (Husserl 2008, 350).

${ }^{10}$ Here Husserl makes use of the term "concept" and occasionally Husserl even uses the terms essences and concepts synonymously. Since such a terminology is misleading, in Ideas I Husserl provides the following clarification: "If concepts are psychical formations then those affairs, such as pure numbers, are not concepts. But if they are concepts, then concepts are not psychical formations. As a consequence, one needs new terms if only to resolve ambiguities as dangerous as these." (Husserl 1982, 42).
} 
experiences, I still would have a priori insights. It might well be that a priori insights depend for their existence or genesis on foregoing experiences. ${ }^{11}$ The point simply is that they do not for their justification depend on the validity of any experience.

Positively, Husserl characterizes immediate a priori insight as a seeing of how the state of affairs in question is a consequence of the involved essences. A priori insight or apodictic ${ }^{12}$ evidence does not occur when a state of affairs strikes me as being (necessarily) true. A priori insights are not empty intentions but full intuitions. I can know that 2 is the only even prime number because my teacher or my textbook says so. But I can also grasp or see that this has to be so since every even number greater than 2 can be divided by two and hence cannot be a prime number. Such an a priori insight is an apodictic evidence characterized by Husserl as "the consciousness of seen, actually experienced necessity." (Husserl 1984, 122)

So far, we have discussed one shortcoming of empiricism. This is that it leads to skepticism since it cannot allow for the immediate a priori grasping of general epistemological principles. The other shortcoming of empiricism, according to Husserl, is its unwarranted restriction of experience to sensory (and introspective) intuition. Husserl insists that every originary presentive intuition is a source of immediate justification and that also a priori intuitions are originally presentive. The locus classicus here is chapter two of Ideas I entitled "naturalistic misinterpretations."

The essential fault in empiricistic argumentation consists of identifying or confusing the fundamental demand for a return to the 'things themselves' with the demand for legitimation of all cognition by experience. With his comprehensible naturalistic constriction of the limits bounding cognizable 'things,' the empiricist simply takes experience to be the only act that is presentive of things themselves. But things are not simply mere things belonging to Nature, nor is reality in the usual sense simply all of reality; and that originarily presentive act which we call experience relates only to reality in Nature. (Husserl 1982, 35 f.; translation modified as I translate "Wirklichkeit" as "reality" and not as "actuality")

Husserl suggests substituting "experience" with "intuition" (Husserl 1982, 37) and he makes clear that every originary presentive intuition is a source of immediate justification (cf. Husserl's principle of all principles in $\$ 24$ ). On top of that, he affirms that '[i]mmediate 'seeing,' not merely sensuous, experiential seeing, but seeing in the universal sense as an originally presentive consciousness of any kind whatever,

\footnotetext{
11 In fact, as we shall see, Husserl subscribes to the claim that all categorial intuitions including all eidetic intuitions are founded on straightforward sense experiences. But founding, in Husserl's terminology, is a relation of existential dependence not of justificatory dependence. We will discuss this in more detail at the end of this section.

12 In Husserl's terminology, not only a priori intuitions but also introspective or immanent acts can have the character of apodicticity in the sense of presenting their contents as indubitable. However, there are important differences in how introspective acts and a priori intuitions present their contents and when Husserl characterizes apodictcity as "the consciousness of seen, actually experienced necessity," as we shall see below, he clearly has in mind the character of a priori intuitions. This is also how I use this term in this paper.
} 
is the ultimate legitimizing source of all rational assertions." (Husserl 1982, 36) Originary presentive intuition aka immediate seeing is not only an immediate but also the ultimate source of epistemic justification. Since sensory experiences such as my visual perception of a table in front of me qualify as originary presentive intuitions, Husserl is committed to the claim that sensory experiences are an autonomous and immediate source of justification. By this I mean that having a sensory experience that $\mathrm{p}$ is sufficient for having propositional justification for believing that $\mathrm{p} .{ }^{13}$ Of course, it is the task of philosophers to investigate the underlying epistemological principles such as the principle of all principles that elucidates that sensory experiences, qua being originary presentive acts, are an immediate source of justification. The point is that a person who has an originary presentive intuition that $p$ is not in need of knowing the a priori principle of principles in order to be justified in believing p. An epistemological principle such as the principle of all principles is "not a principle I have to apply in order to gain knowledge; I need only fall under it" (Van Cleve 1979, 70). Walter Hopp discusses this in detail in Hopp (2009) and concludes that Van Cleve's dictum "is just what we find phenomenologically." (Hopp 2009, 11)

Husserl's claim that sensory experiences qua being originary presentive intuitions are an immediate source of justification is one of the empiricist motives we find in his epistemology. His claim that originary presentive intuitions are the ultimate source of justification reveals that Husserl is a foundationalist. ${ }^{14}$ His insistence that a priori intuitions (just as sensory experiences) are originally presentive and thus a source of immediate (prima facie) justification qualifies him as a rationalist. Husserl praises empiricism for its ambition to focus only on what is originally given and to refute all appeals to tradition or other authorities besides "autonomous reason" (Husserl 1982, 35). What empiricists overlook, however, is that originary givenness must not be restricted to the sensory but has to include the essences which can be given a priori and apodictically. In this sense, Husserl says: "If 'positivism' is tantamount to an absolutely unprejudiced grounding of all sciences on the 'positive,' that is to say, on what can be seized upon originaliter, then we are the genuine positivists." (Husserl 1982, 39)

Husserl, in an anti-naturalistic spirit, does not classify experiences according to the bodily organs that produce them. He does not link justificatory force to causality or other external factors such as reliability or truth. What counts for him is how acts present their contents, how objects are given within the respective acts. What is important is whether an act is originally presentive, i.e., whether it presents its object in a "fleshed out" manner as "bodily present." If so, the act in question is a justification-conferring act no matter how it is produced..$^{15}$ In this sense, Husserl says that originary presentive intuition "has its legitimizing function only because,

\footnotetext{
13 Of course, such justification is prima facie justifiaction, i.e., justification that can be defeated for instance by further experiences.

14 For more details on Husserl's foundationalism cf. Berghofer (2018a).

15 Again, such justification is prima facie justification. If we have a perfect hallucination that $p$, we are justified in believing that $\mathrm{p}$, but if we find out that the respective experience is hallucinatory, the justification provided by this hallucination is defeated.
} 
and to the extent that, it is an originally presentive source." (Husserl 1982, 36) All that counts is the phenomenal character of the act, not any external factor. In this sense, Husserl is an epistemic internalist. This can already be seen in the Sixth Logical Investigation when Husserl shows how sensuous intuitions and categorial ${ }^{16}$ intuitions are internally related and what distinguishes them from signitive or empty acts.

Plainly the connection between the wider and narrower, the supersensuous (i.e. raised above sense, or categorial) and sensuous concept of perception, is no external or contingent matter, but one rooted in the whole business on hand. It falls within the great class of acts whose peculiarity it is that in them something appears as 'actual', as 'self-given'. Plainly this appearance [my emphasis] of actuality and self-givenness (which may very well be delusive) is throughout characterized by its difference from essentially related acts through which alone it achieves full clarity - its difference from an imaginative 'making present', or from a merely significative 'thinking of', which both exclude 'presence' (so to say appearance 'in person'), though not excluding the belief in being. (Husserl 2001a, 281)

Husserl leaves no doubt that straightforward sensuous intuitions and categorial intuitions are not united by external factors but by the "appearance of actuality and self-givenness." Furthermore, he stresses that this appearance "may very well be delusive." The fallibility of experiences is a fact that does not undermine their justificatory force. We shall return to this in Sect. 3. Further similarities between the Logical Investigations and Ideas I are that Husserl again emphasizes that empiricism leads to skepticism (Husserl 1982, §20) and that he insists that a priori intuitions tell us something about reality. We have already quoted the passage in which Husserl says that "things are not simply mere things belonging to Nature, nor is reality in the usual sense simply all of reality; and that originarily presentive act which we call experience relates only to reality in Nature." (Husserl 1982, 35 f.; translation modified) While sense experiences have as intentional objects physical objects, eidetic intuitions (= a priori intuitions) have essences as objects. For Husserl, it is a mistake to restrict reality to "reality in Nature" just like it is a mistake to restrict originary presentive intuitions to sensory experiences.

What precisely Husserl means by reality is of course hotly debated and it would go beyond the scope of this paper to investigate whether Husserl is a metaphysical realist, idealist, or neither of both. The point is that essences are as real as physical

\footnotetext{
${ }_{16}$ Having a categorial intuition means intuiting a categorial object such as a state of affairs. Thus, the "original type" of categorial intuitions and categorial judgments is the form "S is p." (Husserl 1973, 318) Seeing a black laptop is an example of a straightforward sensuous experience. Seeing that the laptop is black is a categorial intuition founded on the straightforward sensuous experience. Importantly, categorial intuitions are not limited to perceptual experiences. Indeed, in $§ 52$ of the Sixth Logical Investigation Husserl argues that eidetic intuition are categorial intuitions founded on straightforward sensuous experiences. This is also the received view (cf. Kidd 2014; Moran and Cohen 2012, 91). Intuiting that a physical object cannot be green all over and red all over at the same time would be an example of an eidetic intuition that is clearly categorial. However, since seeing the eidos green, for instance, would also be an example of an eidetic intuition, I am hesitant to consider all eidetic intuitions categorial.
} 
objects and that a priori intuitions do not reveal how we use concepts but structures of reality. In this context Husserl insists that essences are not merely "grammatical hypostatization," nor "psychological processes of 'abstraction'", nor "mental constructs," nor "products of abstraction." (Husserl 1982, 41 f.) Essences are as real as it gets. ${ }^{17}$ Husserl even states that "[b]lindness to ideas is a kind of psychical blindness; because of prejudices one becomes incapable of bringing what one has in one's field of intuition into one's field of judgment." (Husserl 1982, 41) In a Fregean fashion, he claims that in truth 'all human beings see 'ideas' 'essences,' and see them, so to speak, continuously; they operate with them in their thinking, they also make eidetic judgments-except from their epistemological standpoint they interpret them away."18 (Husserl 1982, 41) He then moves on to declare that "the number two," like every number, "is an atemporal being." (Husserl 1982, 42) Husserl's statement that numbers are atemporal beings is clearly anti-conceptualist since it implies that numbers are mind-independent entities ${ }^{19}$ which indicates that Husserl's rationalism is linked to a form of platonism. ${ }^{20}$ Tellingly, in Formal and Transcendental Logic Husserl complains:

Nothing else hindered a clear insight into the sense, into the proper questions and methods, of genuine transcendental philosophy so much as did this antiPlatonism, which was so influential that it actuated all parties, and even the thinking of a Kant, struggling to free himself from empiricism. (Husserl 1969, 259)

We shall conclude this section by summarizing what is empiricist and what is rationalist about Husserl's epistemological system.

Empiricist motifs in Husserl's epistemology:

E1: Experiences are an autonomous source of immediate justification

E2: No a priori reasoning is needed to infer the existence of the world or of physical objects

E3: Induction is a legitimate source of justification

E4: Coherence is epistemologically important

\footnotetext{
${ }^{17}$ Husserl makes clear that his insistence that ideal objects such as numbers really exist is not "a mere façon de parler" (Husserl 2001a, 250).

18 Similarly, Brown states that, "Mathematicians are instinctively realists; but when forced to think about the details of this realism, they often become uneasy." (Brown 2008, vii).

19 It is to be noted that in the texts of Husserliana XXXVI Husserl explicitly states that the existence of numbers does not depend on an existing consciousness (Husserl 2003, 74, 120, $139 \mathrm{f}$.). Thus, numbers and essences in general are not products of human minds.

20 David Kasmier rightly points out that "Husserl's development of phenomenology, to his own mind, depended straightforwardly on the metaphysical reality of universals and the epistemological possibility of a priori knowledge." (Kasmier 2010, 21). One of Husserl's clearest commitments to the thesis that "ideas are objects" that are non-spatiotemporal but nevertheless exist can be found in Husserl (1996, 31-33) where he states that this thesis is "ganz scharf, blutig ernst gemeint." For an enlightening discussion of this passage and its realist implications cf. Erhard $(2014,96)$. For discussions of Husserl's platonism cf., e.g., Rosado Haddock (2010) and Tieszen (2011).
} 
We have elaborated on E1 when we discussed Husserl's claim that every originary presentive intuition is a source of immediate justification. E2 distinguishes Husserl's rationalism from Descartes' since the latter infers from the existence and benevolence of God that the external world exists and that our sensory experiences are mostly veridical. E3 and E4 do not play an important role in this paper; for a detailed analysis cf. Berghofer (2018a).

It is to be noted that while E1-E4 are typically associated with empiricism, they are not sufficient for characterizing an epistemological system as empiricist. To put it differently, rationalists have traditionally rejected these claims but there is no systematic reason why they must refute them. We shall see that Husserl's epistemological system is a rationalism that incorporates these claims. What is rationalist about Husserl's epistemology is that he holds not only that a priori justification is possible but that a priori insights tell us something about reality. What is distinctive about Husserl's rationalism is that he takes certain experiences to be the source of immediate a priori justification. These experiences are eidetic or a priori intuitions and bear the mark of originary givenness. ${ }^{21}$ What is unique about Husserl's rationalism is that he holds that a priori intuitions gain their justificatory force precisely by virtue of their originary givenness. ${ }^{22}$ In the next section, we shall see how (moderate) rationalism is characterized in current analytic epistemology.

\section{What is Moderate Rationalism?}

It is well-known and unsurprising that Husserl's rationalism, i.e., his claim that a priori insights about reality are possible, or, to put it differently, his commitment to the possibility of a synthetic or material a priori, have not been well received by logical empiricism. ${ }^{23}$ Here Moritz Schlick is Husserl's main adversary. While it has been said that the refutation of psychologism is "the one and only point on which Schlick agreed with Husserl" (Feigl and Blumberg at page XXI in their introduction to Schlick 1974), it should be mentioned that Schlick acknowledged the clarity of Husserl's Logical Investigations. When Schlick criticized what he called the "independence theory of truth" he chose Husserl as his main opponent since "his investigations assuredly represent a very thorough discussion of the absolute standpoint, and have exerted a very considerable influence upon current philosophical literature." (Schlick 1979, 51) Furthermore, Schlick acknowledged Husserl's good knowledge of mathematics (Schlick 1979, 143). However, Schlick raised two important objections against Husserl. The first one is the aforementioned objection against Husserl's independence theory of truth Schlick put forward in his "Das Wesen der

\footnotetext{
${ }^{21}$ In this context David Woodruff Smith states that "Husserl's doctrine of intuition can be seen as a radical extension of empiricism, sweeping rationalism and empiricism together in a wide notion of intuition." (Smith 2007, 322).

22 In this paper, I will not shed much light on this aspect. For more details cf. Berghofer (2018b).

23 "But from fairly early on there was widespread agreement among the logical empiricists that there was no synthetic a priori, and that logic and mathematics and perhaps much else that seemed impervious to empirical disconfirmation should be thought of as analytic." (Creath 2017, section 4.2).
} 
Wahrheit in der Modernen Logik" (1910). Here Schlick objected to the claim that the truth of propositions is objective in the sense of being independent of any subject. In the Prolegomena Husserl argues that there are truths with respect to mathematical problems even if these problems are so complicated that it is psychologically impossible to know these truths (Husserl 2001a, 118). ${ }^{24}$ In this context Husserl refers to examples such as the n-body problem and trillion-placed decimal numbers. Referring to Husserl's discussion, Schlick claims: "But now does this example of Husserl's prove that there are true propositions which yet can never be inwardly evident to man? No!" (Schlick 1979, 52).

In this context I merely wish to point out that in current epistemological debates Husserl's independence theory of truth is much more popular than Schlick's refusal. ${ }^{25}$ Influenced by Bolzano, Husserl advocates the abstractness or ideality of propositions and truth-values. Frege here is on the same page and by now "it is customary to label truth values as abstract objects." (Shramko and Wansing 2017, section 1.3) While Husserl's endorsement of objective (logical, mathematical, etc.) truths is one important element of his rationalism, Schlick's second main objection against Husserl disputes the main thesis of rationalism. This is Schlick's objection that there are no a priori insights about reality. The locus classicus for this is Schlick's "Gibt es ein materiales Apriori?" (1932).

First, Schlick expresses his discomfort about phenomenologists introducing a new type of experience namely eidetic or a priori intuition (Schlick 2008, 456). He points out that according to empiricism, a priori statements can only be analytic statements. A priori judgments are possible, mathematical statements, for instance, are considered analytic statements, but there is no material or synthetic a priori. Furthermore, he makes clear that he prefers the term tautological to analytic. ${ }^{26}$ Thus, according to Schlick, all a priori is tautological (Schlick 2008, 460). A further characteristic of such tautological sentences is their triviality (Schlick 2008, 463, 465). At the end of the paper, he reinforces that a priori sentences can only be "formaltautological" and "do not reveal anything about reality" but only about "the content of our concepts, i.e., the manner how we use our words." Being "vacuous formulas they contain no knowledge and cannot be the foundation of a particular science." (Schlick 2008, 469).

The first thing to note is that it is plainly absurd to state that mathematics is a priori but that all a priori is trivial and incapable of providing knowledge or being a foundation of science. Is mathematics trivial? Are Gödel's incompleteness theorems

\footnotetext{
${ }^{24}$ In Husserl's terminology: Evidence with respect to these truths is only ideally possible but psychologically impossible.

${ }^{25}$ However, it is to be noted that Husserl's Sixth Logical Investigation seems to link truth to evidence, which is why Husserl is often interpreted as championing an epistemic conception of truth. For more details on this discussion cf. Zuidervaart (2017, chapter 6).

${ }^{26}$ In the literature, it is frequently pointed out that Husserl's conception of analyticity is clearer and narrower than Schlick's (cf., e.g., Simons 1992). Thus, one might wonder whether the whole debate between Husserl and Schlick is simply a terminological issue. It is not. As Piazza has rightly pointed out, at the core of the debate there "is a disagreement about whether a priori knowledge is, and can be informative knowledge about reality." (Piazza 2004, 235) Husserl affirms and Schlick denies this possibility.
} 
trivial? Mathematics is neither trivial in the sense of being easy nor in the sense of being unimportant for knowledge about the physical world. ${ }^{27}$ When by saying that all a priori statements are tautological, Schlick means that understanding the terms involved is sufficient for seeing their truth, he may be right, but this in no way entails that such statements cannot tell us anything about reality.

There are many a priori statements phenomenologists consider crucially important. Such statements are epistemological principles such as "Every originary presentive intuition is a source of immediate justification" or phenomenological insights such as "Physical objects can only be given in perspectives," and "All experiential consciousness is intentional." When Schlick investigates whether there is a material a priori, referring to Scheler he discusses the infamous statement that the same object cannot be green all over and red all over at the same time (Schlick 2008, 461). ${ }^{28}$ Unsurprisingly, he comes to the conclusion that this statement is tautological for which its triviality is an indication.

The empiricism of the logical positivists according to which there can only be synthetic a posteriori statements and analytic a priori statements was fiercely attacked in the second half of the twentieth century. Interestingly enough, this attack was not launched by rationalists but by more radical empiricists. The author of this radical empiricism was Quine who not only questioned the possibility of a material a priori but of the a priori in general. According to Quine, there is no a priori. All justified beliefs gain their justification solely on empirical grounds.

In the light of this development, it seems that phenomenology due to its commitment to eidetic intuition and thus to the possibility of a priori insights is hopelessly outdated. However, the end of the twentieth century has seen a revival of rationalism that has been famously dubbed a "rationalist renaissance" (Bealer 2002). This revival is most obviously exemplified by the prominent role rational intuitions play in contemporary philosophy. There is considerable agreement that "intuitions are presented as our evidence in philosophy" (Williamson 2007, 214) and that "analytic philosophy without intuitions just wouldn't be analytic philosophy" (Weinberg 2007, 318; cf. also Pust 2000, xiii). The reliance on intuition is considered as one of the defining features of philosophy: "One thing that distinguishes philosophical methodology from the methodology of the sciences is its extensive and avowed reliance on intuition." (Goldman 2007, 1) The importance of rational intuition in current philosophy signifies anti-naturalistic and anti-empiricist tendencies. It is antinaturalistic because it reveals that the natural sciences and philosophy differ in their respective methodologies. It is anti-empiricist since it highlights the importance of the a priori. This renaissance of rationalism has been made possible by a transition from strong, traditional rationalism to moderate rationalism. Among the early

\footnotetext{
27 In this context just think about the applicability of mathematics to the physical world and which crucial role it plays in all natural sciences and especially in physics. As Wigner has famously said: "The miracle of the appropriateness of the language of mathematics for the formulation of the laws of physics is a wonderful gift which we neither understand nor deserve." (Wigner 1960).

28 Husserl makes a similar claim in Husserl (2002a, 229 f).
} 
notable proponents of such a moderate rationalism are Robert Audi, George Bealer, and Laurence BonJour.

In what follows, I shall focus on moderate rationalism as outlined by BonJour since he, in my opinion, has most clearly differentiated between moderate/radical empiricism and traditional/moderate foundationalism. We shall see that Husserl's epistemological system qualifies as a moderate rationalism.

In his In Defense of Pure Reason BonJour introduces rationalism as the claim that "a priori justification occurs when the mind directly or intuitively sees or grasps or apprehends (or perhaps merely seems to itself to see or grasp or apprehend) a necessary fact about the nature or structure of reality." (BonJour 1998, 15 f.) Accordingly, we can define rationalism as the thesis that (a) a priori justification is possible and (b) a priori insights tell us something about reality. In the previous section, we have seen that Husserl subscribes to both of these claims, which makes him a rationalist. Furthermore, BonJour distinguishes between traditional and moderate rationalism. Traditionally, rationalists have made two further assertions: "first that such justification not only involves no positive appeal to experience but also is incapable of being refuted or even undermined by experience to any degree; and second, that knowledge justified in this way is certain or infallible, incapable of being mistaken." (BonJour 1998, 16) BonJour points out that these claims are not only problematic but that there is no genuine reason why rationalists should subscribe to them. Moderate rationalism is rationalism without these two further assertions. Currently, virtually every proponent of rationalism is a moderate rationalist.

With respect to empiricism, BonJour distinguishes between moderate and radical empiricism. Moderate empiricism is the view that a priori justification is possible but that a priori insights can only be analytic and are incapable of providing insights concerning the nature and structure of reality (BonJour 1998, 18). Radical empiricism bluntly denies the possibility of a priori justification (BonJour 1998, 19). Accordingly, logical positivists qualify as moderate empiricists while Quineans are radical empiricists. BonJour provides a positive and a negative characterization of a priori insight: "a proposition is justified a priori if it is justified (a) independently of any appeal to experience and (b) by appeal to reason or pure thought alone."29 (BonJour 1998, 7) While Husserl agrees with the negative aspect of this characterization (cf. Husserl 2008, 231), there are some differences concerning the positive aspect. ${ }^{30}$ For Husserl, on the positive side, a priori intuitions are characterized as originary presentive intuitions that are directed at essences and possess the character of apodicticity. These differences concerning the positive characterization of the a priori do not concern us here but in the following section I will clarify what it means for an

\footnotetext{
29 BonJour points out that this epistemic independence from experience does not mean that experiences cannot play a crucial role concerning the genesis of a priori insights. Understanding the terms involved may only be possible due to foregoing experiences (cf. BonJour 1998, 10, 107).

30 This can be more clearly seen when BonJour continues to differentiate a priori insights from sensory experiences by characterizing the latter as "being a causally conditioned response to particular, contingent features of the world." (BonJour 1998, 8) Husserl, on the other hand, distinguishes between different types of intuitions phenomenologically, i.e., without referring to external factors such as causality but to how the respective intuitions present the objects they are directed at.
} 
intuition to possess apodicticity. It is to be noted, however, that in a later work BonJour has shifted to a more phenomenological characterization:

[A priori insights] are not supposed to be merely brute convictions of truth, on a par with the hunches and fears that may simply strike someone in a psychologically compelling way. On the contrary, a priori insights at least purport to reveal not just that the claim is or must be true but also, at some level, why this is and indeed must be so. (BonJour 2014, 179)

BonJour's defense of rationalism is threefold and consists of (1) providing intuitively plausible candidates for a priori insights about the structure of reality, (2) demonstrating the untenability of empiricism, and (3) defending rationalism against popular objections. Concerning (1), BonJour, e.g., discusses the familiar example "that nothing can be red all over and green all over at the same time." ${ }^{1}$ (BonJour 1998, 100-102) Contrary to Schlick and in accordance with phenomenologists, he takes this example to support rationalism. Regarding (2), BonJour's argument delivered in chapter 1 perfectly resembles Husserl's general attack on empiricism in the Prolegomena that we have discussed in the previous section. Like Husserl, BonJour focuses on mediate empirical knowledge. Granted that sensory experiences provide non-inferential justification for what is directly experienced, BonJour poses the following problem:

The obvious and fundamental epistemological question then becomes whether it is possible to infer, in a way that brings with it epistemic justification, from these foundational beliefs to beliefs whose content goes beyond direct experience or observation: beliefs about the past, the future, and the unobserved aspects of the present; beliefs that are general in their content; or beliefs that have to do with kinds of things that are not directly observable. (BonJour 1998, 4)

This is a dilemma for empiricists since a negative answer leads to "extremely severe forms of skepticism" but a positive answer acknowledges the epistemic importance of the a priori (BonJour 1998, 4). Thus, "empirical knowledge must involve an indispensable a priori component-so that the only alternative to the existence of a priori justification is skepticism of the most radical kind." (BonJour 1998, 3) BonJour continues to generalize this argument by applying it to all kinds of reasoning. With respect to any argument you can pose the following question: "is there any reason for thinking that the conclusion of the argument either must be true or else is likely to be true if the premises are true?" (BonJour 1998, 5) BonJour concludes that no argument can "be entirely justified on empirical grounds" which means "that the repudiation of all a priori justification is apparently tantamount to the repudiation of

\footnotetext{
31 As noted earlier, Husserl discusses a similar example in Husserl (2002a, 229 f.) With respect to BonJour's second example "that if a certain person A is taller than a second person B and person B is taller than a third person C, then person A is taller than person C" (BonJour 1998, $102 \mathrm{f}$.), it ought to be pointed out that Husserl delivers an analogous example concerning higher and deeper sounds (Husserl 1984, 234).
} 
argument or reasoning generally, thus amounting in effect to intellectual suicide."32 (BonJour 1998, 5).

Both BonJour and Husserl not only champion rationalism and reject empiricism but they do so for the very same reasons. In the following section, I shall show that Husserl agrees with BonJour also in subscribing to moderate rationalism. Before that, however, I would like to point out a crucial difference between BonJour and Husserl. Traditionally, rationalists have neglected that sensory experiences are capable of providing non-inferential justification. This is a consequence of their mistaken insistence on the infallibility of non-inferential justification. Since examples of hallucinations and illusions reveal that perceptual justification is fallible, it cannot be immediate. When I see that there is a table in front of me, my sensory experience is not sufficient for justifying the respective belief but needs epistemic support from a priori reasoning such as that a benevolent God exists who would not allow that my sensory experiences are mostly non-veridical.

For very different reasons, BonJour agrees with traditional rationalism that perceptual beliefs cannot be foundational, i.e., immediately justified. According to him, my belief that there is a table in front of me is justified because the existence of a table in front of me is the best explanation for my experience of a table in front of me (cf. BonJour 2003). This means that BonJour agrees with traditional foundationalists that sensory experiences need support from a priori reasoning.

His [BonJour's] answer to the latter question is internalist and foundationalist, in that it takes the justification for claims about the external world to begin from apperceptions of present states of consciousness (mainly sensory consciousness) and to proceed from there on the basis of (allegedly) a priori reasoning, specifically an argument that the truth of our beliefs about the external world constitutes the best explanation of our sensory experience. (BonJour and Sosa 2003, 1)

This is a crucial difference to Husserl since-as we have seen in the previous section-for Husserl every originary presentive intuition is a source of immediate justification. Sensory experiences are a prime example of originary presentive intuitions. It is to be noted that many current rationalists side with Husserl in allowing for immediate perceptual justification. ${ }^{33}$

\section{Fallibility and Corrigibility of a Priori Justification}

We have seen that what distinguishes traditional from moderate rationalism is that traditionally rationalists have claimed that a priori insights can neither be refuted nor undermined on empirical grounds and that a priori justification in general is

\footnotetext{
32 BonJour's argument that a priori justification is indispensable for inferential reasoning has been attacked by Casullo (2003). For a defense and advancement of BonJour's (and Husserl's) indispensable argument cf. Thurow (2009).

33 It should be mentioned that BonJour seems to weaken his position in BonJour (2007).
} 
infallible-a priori insights cannot be wrong. Moderate rationalists deny these claims. To be sure, moderate rationalists are not committed to the claim that there is no single a priori justified belief that is infallible or cannot be undermined on empirical grounds. Maybe my belief that $1<2$ is infallibly justified. The point is that moderate rationalists are not committed to the claim that infallibility is a necessary feature of the a priori. Considering that virtually every traditional rationalist has subscribed to the infallibility thesis, one might wonder why in the past 30 years rationalists have abandoned this claim. BonJour cites three main reasons for abandoning the infallibility thesis: (1) Historical examples in mathematics and logic that were "universally regarded as self-evident by the leading minds in the field in question at a particular time" but turned out to be wrong (BonJour 1998, 111). Here the most famous examples are Euclid's parallel postulate and the unrestricted Comprehension Axiom of naive set theory. (2) Historical examples in rationalist metaphysics that are incompatible with each other (BonJour 1998, 112). BonJour does not go into much detail here, but there is no need to do so. It is well known that philosophers have passionately defended incompatible metaphysical claims and since, at least according to most rationalists, metaphysics is an a priori discipline and since not all incompatible claims can be true, this means that at least some a priori metaphysical insights have been wrong. ${ }^{34}$ (3) The fallibility of a priori insights is a common phenomenon that not only occurs in historical examples but also in our daily lives. Simply pointing out that "there are the routine errors in calculation, proof, and reasoning that are familiar to anyone who has ever engaged in such processes" (BonJour 1998, 112), is the most convincing argument against the infallibility thesis. There is not one single mathematician who has not once considered one of her proofs valid that turned out to be mistaken. More importantly, in our daily lives we often enough make mistakes in our calculations and deductions. In short, the infallibility thesis is untenable. ${ }^{35}$

What does Husserl say concerning the (in)fallibility of a priori insights? In this context I shall argue for two claims: First, there are passages in which Husserl explicitly affirms the fallibility of apodictic insight. Secondly, Husserl's very conception of a priori insight speaks against the infallibility thesis. With respect to the first claim, it ought to be pointed out that I do not deny that there are passages in Husserl's oeuvre, which suggest that he endorses the infallibility thesis. In such passages he may be sloppy in his terminology or he simply may be mistaken. However, in his Formal and Transcendental Logic when explicitly addressing the question of (in)fallibility, he famously states that " $[\mathrm{t}]$ he possibility of deception is inherent in the evidence of experience and does not annul either its fundamental character or its effect." (Husserl 1969, 156) Husserl makes clear that this is true "for every evidence, for every 'experience' in the amplified sense." (Husserl 1969, 156) Thus, "even an

\footnotetext{
${ }^{34}$ Here we can add conflicting epistemological principles. If rationalism is right, then, even if empiricists would not admit this, an empiricist principle such as "Justification can only be empirical," actually is an a priori principle. Thus, if rationalism is right, there are conflicting a priori intuitions about epistemological principles, which suggests that a priori justification is fallible.

${ }^{35}$ For further objections to the infallibility thesis cf. Casullo (1988), Hoffmann (2011), and Jeshion (2000).
} 
ostensibly apodictic evidence can become disclosed as deception and, in that event, presupposes a similar evidence by which it is 'shattered'." (Husserl 1969, 156).

This passage not only reveals that for Husserl even apodictic evidence is fallible, but that such evidence is corrigible. The fact that some of our apodictic insights happen to be mistaken does not imply that we will now and forever be mistaken with respect to our respective beliefs. Evidence can be shattered by evidence and new apodictic investigations can replace former results. Furthermore, Husserl points out that the possibility of deception does not entail the impossibility of epistemic justification. When I see that there is a table in front of me, it is possible that this experience is misleading and is in fact a hallucination. But this does not mean that by having this experience I am not justified in believing that there is a table. The same holds for a priori intuitions. Remember that for Husserl every originary presentive intuition is a source of immediate (prima facie) justification.

One may raise the following concern: Is it really true that the quoted passages from Transcendental and Formal Logical reveal that apodictic evidence for Husserl is fallible? Maybe he wants to say that only evidence that is really true is real evidence and that "evidence" that is misleading is only pseudo-evidence. In this context I want to defend two claims: First, there are compelling interpretative reasons to hold that for Husserl even apodictic evidence is fallible. Second, the view that only true evidence is real evidence leads to an epistemic dead end. Concerning my first claim, we first need to achieve clarity about Husserl's terminology. For Husserl, evidence consists of experiences or more precisely of originary presentive intuitions. The evidence for my belief that there is a table in front of me consists of my sensory experience of a table in front of me. Likewise, my apodictic evidence that $2<3$ consists of my a priori intuition that $2<3$. Of course, I can also rigorously prove that $2<3$. Such a proof provides also a priori justification but only if all the steps in my proof have been accompanied by a priori insights. Importantly, Husserl repeatedly stresses that experiences or perceptions can be in conflict with each other (cf. Husserl 1982, 36 f.; Husserl 1996, 317) and that nothing in the characterization of sensory experience entails that the object of the experience really exists [cf. Husserl $(1973,15)$ and the helpful comments that refer to this passage in Erhard $(2012,57)$ and Soldati $(2012,391)]$. Husserl classifies experiences phenomenologically, from the first-person perspective. It does not matter which type of experience is produced by which bodily organs. The justificatory force of an experience does not depend on the experience being appropriately caused by an external object. Non-phenomenological factors such as truth, reliability, or infallibility are not the factors we are looking for. What matters is the phenomenal character of the experience in question. What matters is how an experience presents its objects.

Before we ask what it is that distinguishes a priori intuitions form sensory experiences we need to ask what it is they have in common. Already in his Logical Investigations Husserl's answer is a phenomenological characterization:

Plainly the connection between the wider and narrower, the supersensuous (i.e. raised above sense, or categorial) and sensuous concept of perception, is no external or contingent matter, but one rooted in the whole business on hand. It falls within the great class of acts whose peculiarity it is that in them 
something appears as 'actual', as 'self-given'. Plainly this appearance [my emphasis] of actuality and self-givenness (which may very well be delusive) is throughout characterized by its difference from essentially related acts through which alone it achieves full clarity - its difference from an imaginative 'making present', or from a merely significative 'thinking of', which both exclude 'presence' (so to say appearance 'in person'), though not excluding the belief in being. [...] In the widest sense even universal states of affairs can be said to be perceived ('seen', 'beheld with evidence'). ${ }^{36}$ (Husserl 2001b, 281)

What sensuous and supersensuous intuitions have in common is that they present their objects in their actuality, they possess the phenomenal character of self-givenness. Husserl explicitly states that it is their appearance of actuality and self-givenness that distinguishes them from mere signitive acts. Here, Husserl leaves no doubt that experiences must be classified phenomenologically and that nothing in the nature or essence of sensory and a priori intuition guarantees truth.

In a highly important text published in Husserliana XXV Husserl complains that the "independence of phenomenology from all empirical knowledge" "has always been viewed as a claim to infallibility, to the impossibility of error." He points out that "this, however, has never been claimed and it also does not follow from the emphasis of the independent legitimacy and the peculiarity of eidetic cognition." He makes clear that every scientific cognition is fallible and he highlights that despite "the countless errors that have occurred in the history of mathematics and logic, no one feels obliged to contest" their evidential status (Husserl 1987, 246).

Since it is clearly not the feature of infallibility, how does Husserl distinguish apodictic from sensory intuition? The answer, of course, can only be a phenomenological difference in how the respective experiences present their objects. The difference must be located within the experience itself, i.e., within the phenomenal character of the experience. Accordingly, an evidential insight that $\mathrm{p}$ is apodictic if it presents $\mathrm{p}$ as apodictic, i.e., if $\mathrm{p}$ is experienced as being absolutely indubitable. When I have the a priori insight that 2 is the only even prime number, this insight is apodictic not because I cannot be wrong about this statement but because by understanding the terms involved I can "see" that there is no rational way of doubting this statement. We may say that in the case of physical objects or states of affairs I can see that something is the case, e.g., that there is a table in front of me. By having apodictic evidence, on the other hand, I can see that something must be the case and could not be different, which means I can see why something must be the case, e.g., that 2 is the only even prime number. Apodictic evidence is characterized as "the consciousness of seen, actually experienced necessity." (Husserl 1984, 122) Thus, I fully agree with Gail Soffer, when she states that "[i]nterpreted phenomenologically, that an Evidenz is apodictic can mean only that it presents itself as apodictic, and not that it is apodictic 'in reality', in some Cartesian, objectivist sense of the real." (Soffer 1991, 124) This is also in line with John Drummond's interpretation:

36 This passage was already quoted in Sect. 1 but due to its importance I wanted to quote it again in full length. 
Apodicticity is a property of evidence, and one of the types of absolute evidence that Husserl identifies. An apodictic evidence is indubitable. Apodicticity must be distinguished from both infallibility and incorrigibility. To say that evidence is apodictic does not mean that it is impossible for us to be mistaken or that it is impossible that our insight will be subject to various forms of correction. It means only that we have no good reason to doubt the correctness of our insight. (Drummond 2007, 37 f.)

Thus, we have seen that there is compelling textual evidence that Husserl subscribes to the fallibility ${ }^{37}$ of apriori intuition and that there are systematic reasons why Husserl qua being a phenomenologist should subscribe to the fallibility thesis. Now, let me briefly show why it would be an epistemological dead end to define veridical evidence as real evidence and misleading evidence as pseudo-evidence.

The starting-point of this discussion is that Husserl's statement that "even an ostensibly apodictic evidence can become disclosed as deception and, in that event, presupposes a similar evidence by which it is "shattered" (Husserl 1969, 156) allows for two interpretations.

\section{I1 Apodictic evidence is fallible}

I2 We need to distinguish between veridical or factive apodictic evidence on the one hand and misleading or pseudo-apodictic evidence on the other hand. Only veridical apodictic evidence is true apodictic evidence but it is always possible that what we take to be truly apodictic evidence turns out to be misleading and thus pseudo-apodictic

According to I2, what makes an evidence a truly apodictic evidence is not solely its distinctive phenomenal character but also the external factor of veridicality. This means that proponents of I 2 make a distinction between types of evidence (truly apodictic vs. pseudo-apodictic) that is not purely phenomenological but based on external factors. As argued above, there are systematic-phenomenological reasons not to subscribe to such a non-phenomenological distinction. However, there are also purely epistemological reasons to prefer I1 to I2.

In order to see this more clearly, it is to be noted that the proponent of I 2 could either argue that true apodictic evidence as well as pseudo-apodictic evidence are a source of justification or that only true apodictic evidence has justificatory force. In the former case, I2 leads only to a more complicated terminology but just like I1 it entails the fallibility of a priori beliefs. Say, my justification for my belief that 2 is the only even prime number is based on an a priori intuition that phenomenologically bears the mark of apodicticity. According to I1, this process of justification is fallible because apodictic evidence is fallible. According to I2, my belief is fallible because it could be that this intuition is not truly apodictic but only pseudo-apodictic.

$\overline{37}$ For more details on fallibilist elements in Husserl's thinking cf. Berghofer (2018a). 
In the latter case, however, it would in principle be impossible to know on internal grounds whether one is justified or not. This is because truly apodictic and pseudoapodictic evidence are phenomenologically indistinguishable. If only truly apodictic evidence is a source of justification but I am in no position to know whether my insight is truly apodictic, I am systematically cut off from what makes my beliefs justified. ${ }^{38}$ Thus, at least philosophers with internalist tendencies (such as phenomenologists) should feel more attracted towards I1 than I2.

Having clarified that there is textual evidence that Husserl considers a priori justification to be fallible and that phenomenologists should consider a priori justification to be fallible, let us turn to the question of whether Husserl even allows that a priori justification can be empirically undermined. Husserl's statement that "even an ostensibly apodictic evidence can become disclosed as deception and, in that event, presupposes a similar evidence [my emphasis] by which it is "shattered"' suggests that for Husserl apodictic evidence can only be shattered by apodictic evidence and accordingly that a priori insights can only be undermined by a priori insights. The first thing to note is that this claim is too strong. As a matter of fact, empirical results can undermine a priori reasoning. For more than two thousand years the greatest mathematicians believed on a priori reasons that geometry must be Euclidean and that the parallel postulate is necessarily true. Einstein's theory of general relativity, however, has it that the geometry of spacetime is non-Euclidean and it has been empirically shown that in our universe the parallel postulate is violated. One may object that historically Einstein's general relativity has not undermined the claim that the parallel axiom is necessarily true since non-Euclidean geometries were developed before Einstein's general relativity. ${ }^{39}$ Still, I believe that this shows that it is at least in principle possible that a priori insights can be empirically challenged.

A more down-to-earth example may be more convincing:

You are a math student and as an exercise you have to find out whether a certain mathematical statement (M1) is true. M1 seems intuitively plausible to you. You aim at proving M1 and find a surprisingly easy way to do so. Due to your "proof" you have a priori justification for M1. Shortly before the tutorial you talk to your colleagues and realize that all of them agree that M1 is wrong. Confused you consult your smartphone and realize that according to reliable webpages M1 is an example of a plausible-looking statement that happens to be false.

Are you still justified in believing M1 or has your a priori justification been defeated by your empirical findings? Obviously, there can be empirical defeaters for a priori

\footnotetext{
${ }^{38}$ In this context BonJour says: "To insist that a priori epistemic justification requires a genuine rational insight, in the sense just specified, would make it impossible to tell whether a given claim was justified in this way or not without knowing independently whether or not the claim of necessity was correct-thus making the appeal to rational insight entirely useless as an independent and self-contained basis for justification." (BonJour 1998, 113).

39 It is to be noted, however, that Einstein's results that physical space is not Euclidean provided a significant boost to logical empiricists and were considered by them a confirmation of their refutation of the synthetical apriori (cf. Friedman 2008).
} 
justified beliefs. Interestingly enough, there is an intriguing passage in which Husserl acknowledges this fact. Husserl quotes Elsenhans by posing the following question (Husserl 1987, 248): "'When empirical science corrects what is phenomenologically intuited, should he [the phenomenologist] ignore this correction?"' Husserl gives the following response:

Following the previous remarks, the answer to this cannot be doubtful: Experience [in the sense of empirical evidence] can call the attention of the investigator of essences [Wesensforscher] to the fact that in his findings must be a mistake, it can prompt him to probe these findings in a new intuition and to correct them, but it itself cannot be a correction: Only by eidetic intuition I can gain eidetic insights. (Husserl 1987, 248; my translation)

This is a highly interesting passage that not only reveals that eidetic intuition is fallible but also illuminates that empirical evidence can defeat or at least cast into doubt justification gained by eidetic intuitions. Thus, Husserl subscribes to the following plausible claims that are distinctive for moderate forms of rationalism:

M1: A priori justification is fallible

M2: A priori justification can be undermined by empirical evidence

Thus, Husserl is a moderate rationalist.

As a final note, it may be pointed out that even if Husserl holds that empirical evidence can defeat eidetic justification, he still insists that it cannot overrule it. Empirical evidence can lead to a correction - that must be accomplished by a new eidetic intuition-but it "cannot be a correction." Thus, Husserl seems to make the following claim:

\section{M3: A priori justification cannot be corrected by empirical evidence}

I believe that M3 is too strong and fails to acknowledge cases of justification by testimony. If your trustworthy friends, teachers, and textbooks tell you that the mathematical theorem $\mathrm{T}$ obtains, you are (inferentially) justified in believing $\mathrm{T}$ even if you fail to intuit or prove $\mathrm{T}$ (and thus lack a priori justification for $\mathrm{T}$ ) ${ }^{40}$ Importantly, there is no systematic reason why phenomenologists should be committed to M3. An anonymous referee of this journal has rightfully pointed out that I should be more precise on why the phenomenologist is not committed to M3. I take it that in the context of a priori justification a Husserlian-style phenomenologist is committed to the following four theses:

\footnotetext{
40 One might make the plausible claim that a priori justification cannot be corrected on purely empirical grounds in the sense that when a reliable source tells me that theorem T obtains, I need to have reasons to believe that this source is reliable and I need to have a priori reasons to consider reliable sources a source of justification. Still, Husserl's point seems to be that necessary truths can only be a priori justified and cases of justification by testimony show that this is not true. Of course, one can still hold that immediate justification for a priori truths can only be delivered by a priori intuitions.
} 
(1) Phenomenology is independent of the empirical sciences specifically in the sense that eidetic intuitions are an autonomous source of immediate justification. (2) Eidetic intuitions do not merely reveal how we use concepts but can reveal structures of reality. (3) It is possible to a priori intuit basic phenomenological-epistemological principles. (4) Since phenomenology is the eidetic (a priori) science of first principles, it can ground not only its own validity but also the validity of the empirical sciences; in this sense phenomenology is intended to be First Philosophy.

Importantly, these four theses only imply that a priori justification is an autonomous source of justification, it does not imply that a priori sciences and empirical sciences are totally detached from each other in the sense that they could not possibly benefit from each other. More importantly, these theses do not imply that in some cases empirical findings can provide some inferential justification for believing a priori truths. Husserl seems to believe that there cannot be such cases, but cases of justification by testimony, as sketched above, suggest otherwise. Cases of justification by testimony violate M3, but they do not violate the phenomenological core commitments (1)-(4), which is why phenomenologists are not committed to M3.

The point, however, is that Husserl subscribes to M1 and M2, which means that there is no doubt that Husserl's rationalism is a moderate rationalism.

\section{Conclusion}

Husserl's universal empiricism has it that even a priori intuitions are originary presentive acts and thus a source of immediate justification. Husserl insists that a priori intuitions are not limited to insights about concepts but can be substantive insights about (structures of) reality. Thus, Husserl's universal empiricism is a form of rationalism. More precisely, it is a moderate form of rationalism. This is because for Husserl a priori justification is fallible and even can be undermined by empirical evidence. In these respects, Husserl is in agreement with Laurence BonJour's moderate rationalism. However, Husserl's break with traditional forms of rationalism is even more radical than BonJour's since Husserl considers sensory experiences an autonomous source of immediate justification and does not subscribe to the claim that a priori reasoning is needed to infer the existence of the world or of physical objects. In sum, Husserl offers a phenomenologically consistent and epistemologically plausible account of the a priori.

Acknowledgements Open access funding provided by University of Graz.

Funding Philipp Berghofer is a recipient of a DOC Fellowship of the Austrian Academy of Sciences at the Department for Philosophy at the University of Graz.

Open Access This article is distributed under the terms of the Creative Commons Attribution 4.0 International License (http://creativecommons.org/licenses/by/4.0/), which permits unrestricted use, distribution, and reproduction in any medium, provided you give appropriate credit to the original author(s) and the source, provide a link to the Creative Commons license, and indicate if changes were made. 


\section{References}

Bealer G (2002) Modal epistemology and the rationalist renaissance. In: Gendler T, Hawthorne J (eds) Conceivability and possibility. Oxford University Press, Oxford, pp 71-125

Berghofer P (2018a) Why Husserl is a moderate foundationalist. Husserl Stud 34(1):1-23

Berghofer P (2018b) Husserl's conception of experiential justification: what it is and why it matters. Husserl Stud 34(2):145-170

Berghofer P (2018c) Towards a phenomenological conception of experiential justification. Synthese. https://doi.org/10.1007/s11229-018-1744-5

BonJour L (1998) In defense of pure reason. Cambridge University Press, Cambridge

BonJour L (2003) A version of internalist foundationalism. In: BonJour L, Sosa E (eds) Epistemic justification. Oxford University Press, Oxford, pp 3-96

BonJour L (2007) Are perceptual beliefs properly foundational? In: Timmons M, Greco J, Mele A (eds) Rationality and the good. Oxford University Press, Oxford

BonJour L (2014) In defense of the a priori. In: Steup M, Turri J, Sosa E (eds) Contemporary debates in epistemology, 2nd edn. Wiley, Malden, pp 363-377

BonJour L, Sosa E (eds) (2003) Epistemic justification. Oxford University Press, Oxford

Brown J (2008) Philosophy of mathematics, 2nd edn. Routledge, New York

Casullo A (1988) Revisability, reliabilism, and a priori knowledge. Philos Phenomenol Res 49(2):187-213

Casullo A (2003) A priori justification. Oxford University Press, Oxford

Creath R (2017) Logical empiricism. In: Zalta EN (ed) The stanford encyclopedia of philosophy (Fall 2017 Edition). https://plato.stanford.edu/archives/fall2017/entries/logical-empiricism/

Drummond J (2007) Historical dictionary of Husserl's philosophy. The Scarecrow Press, Lanham

Erhard C (2012) Husserls moderater empirischer Fundamentalismus und das Verhältnis zwischen Phänomenologie, Ontologie und Metaphysik. Kommentar zu Christian Beyer. In: Welt der Gründe, ed. Julian Nida-Rümelin \& Elif Özmen. Meiner, Hamburg, pp 48-62

Erhard C (2014) Denken über nichts - Intentionalität und Nicht-Existenz bei Husserl. De Gruyter, Berlin Friedman M (2008) Einstein, kant, and the a priori. Royal Inst Philos Suppl 63:95-112

Goldman A (2007) Philosophical intuitions: their target, their source and their epistemic status. Grazer Philos Stud 74(1):1-26

Hoffmann G (2011) Two kinds of a priori infallibility. Synthese 181:241-253

Hopp W (2009) Phenomenology and fallibility. Husserl Stud 25:1-14

Husserl E (1969) Formal and transcendental logic (trans: Cairns D). Martinus Nijhoff, The Hague

Husserl E (1971) "Phenomenology", Edmund Husserl's article for the encyclopaedia Britannica (1927): new complete translation by Richard E. Palmer. J Br Soc Phenomenol 2(2):77-90

Husserl E (1973) Ding und Raum. Vorlesungen 1907. Husserliana XVI. Martinus Nijhoff, The Hague

Husserl E (1982) Ideas pertaining to a pure phenomenology and to a phenomenological philosophy, first book (trans: Kersten F). Martinus Nijhoff, The Hague

Husserl E (1984) Einleitung in die Logik und Erkenntnistheorie. Vorlesungen 1906/07. Husserliana XXIV. Nijhoff, Dordrecht

Husserl E (1987) Aufsätze und Vorträge (1911-1921). Husserliana XXV. Martinus Nijhoff, The Hague

Husserl E (1996) Logik und allgemeine Wissenschaftstheorie. Husserliana XXX. Kluwer Academic Publishers, Dordrecht

Husserl E (2001a) Logical investigations, vol 1 (trans: Findlay JN). Routledge, London

Husserl E (2001b) Logical investigations, vol 2 (trans: Findlay JN). Routledge, London

Husserl E (2002a) Logische Untersuchungen. Ergänzungsband. Erster Teil. Husserliana XX/1. Kluwer Academic Publishers, Dordrecht

Husserl E (2002b) Einleitung in die Philosophie. Vorlesungen 1922/23. Husserliana XXXV. Kluwer Academic Publishers, Dordrecht

Husserl E (2003) Transzendentaler Idealismus. Texte aus dem Nachlass (1908-1921). Husserliana XXXVI. Kluwer Academic Publishers, Dordrecht

Husserl E (2008) Introduction to logic and theory of knowledge: lectures 1906/07 (transl: Claire Ortiz Hill). Springer, Dordrecht

Jeshion R (2000) On the obvious. Philos Phenomenol Res 60(2):333-355 
Kasmier D (2010) A defense of Husserl's method of free variation. In: Vandevelde P, Luft S (eds) Epistemology, archaelogy, ethics: current investigations of Husserl's Corpus. Continuum, London, pp $21-40$

Kidd C (2014) Husserl's phenomenological theory of intuition. In: Osbeck L, Held B (eds) Rational intuition. Cambridge University Press, Cambridge, pp 174-191

Moran D, Cohen J (2012) The Husserl dictionary. Continuum, London

Piazza T (2004) The quest for the synthetic a priori: Husserl and Schlick's debate revisited. In: Chrudzimski A, Huemer W (eds) Phenomenology and analysis. Ontos, Frankfurt, pp 233-256

Pust J (2000) Intuitions as evidence. Routledge, New York

Rosado Haddock GE (2010) Platonism, phenomenology, and interderivability. In: Hartimo M (ed) Phenomenology and mathematics. Springer, Dordrecht, pp 23-46

Schlick M (1974) General theory of knowledge (trans: Blumberg AE). Springer, New York

Schlick M (1979) Philosophical papers: volume I (trans: Heath P). D. Reidel Publishing Company, Dordrecht

Schlick M (2008) Die Wiener Zeit: Aufsätze, Beiträge, Rezensionen 1926-1936. In: Friedl J, Wien HR (eds) Springer

Shramko Y, Wansing, H (2017) Truth values. In: Zalta EN (ed) The stanford encyclopedia of philosophy (Fall 2017 Edition). https://plato.stanford.edu/archives/fall2017/entries/truth-values/

Simons, P (1992) Wittgenstein, Schlick and the a Priori. In: Philosophy and logic in Central Europe from Bolzano to Tarski. Springer, Dordrecht

Smith DW (2007) Husserl. Routledge, London

Soffer G (1991) Husserl and the question of relativism. Kluwer, Dordrecht

Soldati G (2012) Epistemology. In: Luft S, Overgaard S (eds) The Routledge companion to phenomenology. Routledge, London, pp 384-393

Thurow J (2009) The a priori defended: a defense of the generality argument. Philos Stud 146:273-289

Tieszen R (2011) After Gödel: platonism and rationalism in mathematics and logic. Oxford University Press, Oxford

Van Cleve J (1979) Foundationalism, epistemic principles, and the cartesian circle. Philos Rev 88(1):55-91

Weinberg J (2007) How to challenge intuitions empirically without risking skepticism. Midwest Stud Philos 31:318-341

Wigner E (1960) The unreasonable effectiveness of mathematics in the natural sciences. Commun Pure Appl Math 13(1):1-14

Williamson T (2007) The philosophy of philosophy. Blackwell, Oxford

Zuidervaart L (2017) Truth in Husserl, Heidegger, and the Frankfurt School. The MIT Press, Cambridge 